\title{
6 THE USE OF RELIGIOUS MESSAGES ON DIGITAL SOCIAL NETWORKS IN CÓTE D'IVOIRE: ETHICAL CHALLENGES TO SOCIAL COHESION
}

\section{Célestin Gnonzion ${ }^{1}$}

\section{INTRODUCTION}

In Côte d'Ivoire, during the Lenten season marked by Christians, especially the many Catholic Christians in Côte d'Ivoire, a message from the Virgin Mary was at the centre of debates both in local newspapers and on digital social networks on 20 February 2015. This is the message below, delivered to Servant Chantal of the Virgin Mary ${ }^{2}$ and read publicly to a crowd of people present after the Stations of the Cross:

My children, at the beginning of Lent, I invite you more than ever to accept the cross that stands before you. In doing this, you will be in full communion with My Son, your Lord Jesus Christ. Open your hearts to charity in this time of Lent. Pray and do penance. Devote part of your time to silent prayer. Give everyone a good example. Show them by your deeds and your words that you belong to Christ. Your country, in a while, will tremble and abysses will arise. My children will have to wear a heavy cross. Extraordinary phenomena will appear. I already suffer for you. So be strong in prayer, in this Rosary that you make every day at the foot of Ma Souche. Because that's the way you'll show the proofs. All will begin on a Friday, and the Victory of God will come following. You will then be led by him to the great day of victory. ${ }^{3}$

In Côte d'Ivoire, as elsewhere in other countries in the world, but especially in Africa, we have been witnessing, for some years, the expansion of applications and services offered by mobile operators. There has also been a concomitant rise in religious messages on digital social networks, motivated by the Ivorian sociopolitical context, which has been marked by the spectre of a second civil war and political antagonisms with ethnic and religious hints.

It is in this context that two religious leaders were arrested in 2018 for acts of xenophobia and incitement to hatred. One is a Muslim, Imam Aguibou Touré, ${ }^{4}$ and

1 Université Félix Houphouët-Boigny, Department of Information, Communication and Arts.

2 Servante Chantal is a member of the Catholic community of Mary Mother of Christian Charity (MMCC) close to Padre Pio. She delivers periodic messages from the Virgin Mary, usually on Fridays.

3 Online at: http://mariemeredelacharitechretienne.org/accueil.html

4 “Côte d'Ivoire: La poursuite d'Aguibou n'est pas contre les musulmans" [Côte d'Ivoire: The pursuit of Aguibou is not against the Muslims], AfriqueSur7, 14 July 2018. 
the other a Christian, pastor N'goran Koffi Konan Israel. ${ }^{5}$ Côte d'Ivoire experienced a post-election crisis in 2011, following the presidential election between Alassane Ouattara, the current president of the republic, and Laurent Gbagbo, ${ }^{6}$ the losing candidate, who was later deported to the International Criminal Court (ICC). The mobilisation of religions and ethnic groups around these two political leaders by some of their activists has been at the root of some of the recent friction between Muslims and Christians in Côte d'Ivoire. These antagonisms have been brought to light in discussions on social networks, through discussion forums or replies to posts and messages published online.

This multiplication of social networking services has also taken place in a context in which ease of access to messaging services or the internet has benefitted service providers and users alike through the multiple commercial services offered by mobile telephones providers, boosted by competition through granting of free SMS and internet access. Indeed, the number of mobile phone users in Côte d'Ivoire has grown exponentially in recent years. For example, between various services and with some users multiply subscribed, there was mobile phone penetration of $130.75 \%$ of the population as of the last quarter of $2017 .^{7}$ This represents $32,291,295$ for an estimated Ivorian population of 23 million. Subscribers to the internet are estimated at approximately 17 billion, of whom 16,935,794 access via mobile telephone and 118,628 via the fixed telephone. ${ }^{8}$ This represents an internet connection rate of nearly $74 \%$ of the population. ${ }^{9}$ This is a very big step forward when one considers that in prior decades, access to the internet was reserved for a privileged elite. These were mostly executives in public administration or private sector businessmen with high purchasing power. Another novelty in recent years is that the majority of mobile phone users in Côte d'Ivoire now also have access to digital social networks, both in urban and rural areas.

But what elicits our curiosity is what we can call messages with religious connotation or, simply, religious messages - transmitted over digital social networks. This problem was put before the Catholic Church of Côte d'Ivoire when the aforementioned

5 Bony FD. “Religion: Pourquoi le pasteur N'goran a été arrêté, ce que risquent cet homme de Dieu et l'imam Aguibou" [Religion: Why Pastor N'goran has been arrested, risked by this man of God and Imam Aguibou], L'Infodrome, 5 August 2018.

6 Laurent Gbagbo is a former president of the Republic of Côte d'Ivoire from 2000 to 2010. He was an historical opponent qualified by observers as the father of multiparty politics and democracy. But following the 2011 post-election crisis that claimed nearly 3,000 lives, he was charged and transferred to the International Criminal Court (ICC). After more than 7 years of trial, he was acquitted but forbidden to stay in Côte d'Ivoire. He currently resides in Belgium.

7 Autorité de régulation des télécommunications de Côte d'Ivoire (ARTCI) [Telecommunications Regulatory Authority of Côte d'Ivoire]. 2017. “Données statistiques du troisième trimestre 2017" [Statistical data for the third quarter of 2017], November. Online at: http://www.artci.ci/images/stories/pdf/rapport_activite/stat_3e_trimestre_2017.pdf

ARTCI, “Données statistiques".

ARTCI, "Données statistiques". 
message of the Virgin Mary was revealed to Servant Chantal and broadcast over social media. In response, the Catholic bishops of Côte d'Ivoire issued a declaration entitled "Encouraging and calling to the vigilance of bishops to live well on Lent 2015". ${ }^{10}$ Therein, the bishops invited Catholic Christians to "caution and discernment", lest Christians fall into "trouble and panic". ${ }^{11}$

These are also the type of messages interrogated in this chapter. They are religious messages, because they are messages that allude to symbols, words, terms, the name of God or Biblical or Quranic figures, such as the prophets, the Virgin Mary or Christ Jesus. These messages circulate a lot during Christmas, Easter, Ramadan and other religious holidays. They also circulate during periods of social or political tension. For example, the arrests of Imam Aguibou Touré and that of pastor N'goran Koffi Konan Israel mentioned above were broadcast in 2018 on social media networks around the country, arousing many comments and controversies. It was notable they arrived in a context of preparation at the political level for the presidential election of 2020, because crises generally occur after elections in Côte d'Ivoire. As with messages regarding the detention of these two religious leaders, these religious messages were spread on mobile telephones and applications, such as the WhatsApp messaging app or on digital social networks in the form of posts, comments or even email.

The substance of many of these religious messages conveys the primary message of most religions - namely love, peace and tolerance. Some of these positive messages come in the form of prayers, encouragements and blessings. However, others have a negative connotation and activate division, appeal to hatred, arouse fear or even include curses. Examination of religious messages diffused by SMS and social networks suggests a classification of the messages into types:

(1) exhortation and prayers for an outcome favourable to a crisis;

(2) exhortation and prayers for an adverse outcome to a political camp;

(3) alarm information to create psychosis;

(4) messages of blessings to or from a political camp;

(5) messages of curses for or from a political camp; and

(6) insult messages.

The issue that has prompted the present research is that some of these messages may stimulate panic, create psychosis and arouse hatred and xenophobia in a social context already weakened by a history of ethnic and religious political conflict.

10 Conférence des évêques de Côte d'Ivoire [Conference of Bishops of Côte d'Ivoire]. 2015. "Encouragement et appel à la vigilance des Evêques pour bien vivre le Carême 2015" [Encouragement and call to the vigilance of Bishops to live well during Lent 2015]. Online at: http://www.eglisecatholiqueci.org

11 Conférence des évêques de Côte d'Ivoire, "Encouragement et appel à la vigilance des Evêques pour bien vivre le Carême 2015". 
The present study relies upon several approaches for data collection: interviews with religious leaders, collection of messages broadcast on social media networks and mobile phones and interviews with officials of the Telecommunications Regulatory Agency of Côte d'Ivoire (ARTCI) and with residents of Abidjan. The religious leaders interviewed include three imams, three Catholic priests and two evangelical pastors. The imams include the imam spokesperson of the Higher Council of Imams of Côte d'Ivoire (COSIM), the imam of the Plateau Mosque and the imam of the Great Mosque of the Riviera Golf. The Catholic priests are parish priests, Catholic web and television directors and spiritual theology teachers. Also interviewed were two Protestant pastors, one from the Church of Jesus Healing the Nations and another from the Bethesda Evangelical Church.

As a crucial part of the study, the six-part typology of religious messages outlined above was presented to the religious leaders with whom we conducted interviews, using an interview guide around the following points: (1) the observation they make in relation to these religious messages, (2) possible impacts of these religious messages on national cohesion in Côte d'Ivoire, and (3) what religious leaders can do to pacify the faithful in the face of alarming messages and incitement of hatred. But before presenting results, discussion and conclusions on the basis of the collected, it is necessary to shed some further light on some of the basic concepts underlying the present study. The chapter is thus divided into three parts: (1) definition and clarification of concepts, (2) examination of religious messages, and (3) analysis of what religious leaders think of these messages.

\section{MEDIA, COMMUNICATION OF FAITH AND EXPRESSION OF RELIGIOSITY}

\section{The concept of media}

The first word that should be defined in this chapter is "media". It does not seem superfluous to explain and situate it in the framework of this study, even if it is a commonly used word used in this era of digital and new media. One definition of the word "media" to consider is that proposed by a French academic professor and researcher who was also director of the Institute for Research and Study of Communication and Media, Francis Balle, who defines "media" as the "technique used by an individual or a group to communicate to another individual or group, other than face to face (a greater or less distance), the expression of their thought, regardless of the form and purpose of this expression. it allows the transmission of more people, the press, the radio, the television, the displays and the internet" ${ }^{\prime \prime}{ }^{12}$ The media, according to this general definition, is therefore a means of mass communication. But these means can use different channels, such as the web and the services it offers, such as digital social networks.

12 Balle F. 2006. Lexique d'information communication [Glossary of communication information]. Paris: Dalloz, 251. 


\section{The concept of social networks}

Just as the concept of "media" required definition, that of a "social network" should also be specified. According to Thomas Stenger and Alexandre Coutant, ${ }^{13}$ digital social networks are "web services that allow individuals to: (1) build a public or semi-public profile within a system, (2) manage a list of users with whom they share a link, (3) to see and navigate their list of links and those established by others within the system and (4) base their attractiveness essentially on the first three points and not on a particular activity". ${ }^{14}$ The religious messages and their authors, which is the subject of this study, fit the definition of digital social network well, because these authors have built profiles and interact with people in their lists of users with whom they share links and comment on publications. Note that these social networks' lists of users, include ordinary citizens, bloggers, discussion groups and online press media.

\section{Communication of faith}

Why does it seem important for us to shed light on the notion of communication of faith? This is important, because some users and transmitters of religious messages express their faith in their God through prayers or through the evocation of God or other holy persons, addressed as intercessory intermediaries to solve the problems of this world. We start from the definition of the concept of "communication" to examine how this can also be communication of the faith. Communication, according to Francis Balle, is the "consistent action, by people, through exchanging messages, or face-to-face or at a distance, with or without the help of a media, and whatever the form or end of the exchange. The purpose of this exchange is in the context of communicating and communicating." ${ }^{15}$ From this definition, we can grasp the importance of the end of communication of faith. In the communication of the faith, there is an emphasis on the means of mass communication, in other words, the media.

Several studies and publications have highlighted the importance of the media in communicating the faith. In the Catholic Church, the pastoral instruction of the Vatican's Pastoral Council on Social Communication, Aetatis Novae on the twentieth anniversary of their earlier instruction of the Second Vatican Council's Communio et Progressio notes: "The media of social communications can and

13 Alexandre Coutant holds a doctorate in Information and Communication Sciences, and is a researcher in the Laboratory of Management Research Centre (CEREGE), University of Poitier in France. Thomas Stenger is also a doctor in Management Sciences, a research professor at the Institute of Business Administration of Poitier in France, and a scientific leader of the research project "Digital Social Networks (RSN)".

14 Stenger T and Coutant A. 2017. "Les réseaux sociaux numériques: des discours de promotion à la défi nition d'un objet et d'une méthodologie de recherche" [Social networks sites: from promotional messages to the definition of a subject and a research methodology], Hermes - Journal of Language and Communication Studies 23(4):209-228.

Balle, Lexique d'information communication, 82. 
should be instruments in the Church's programme of re-evangelisation and new evangelisation in the contemporary world. In view of the proven efficacy of the old principle "see, judge, act", the audiovisual aspect of evangelisation should be given due attention." 16

But long before, the pastoral instruction Communio et Progressio showed the importance of the media in the proclamation of the Gospel. According to that instruction, "The media are rightly among the most effective resources and possibilities that can be used to strengthen charity, itself a source of communion."17 The instruction of the Second Vatican Council in "Communio et Progressio" continued: "This is why it is all about the reality of social communication and the pursuit of truth and truth. God is going to be a part of the world, fraternally bringing men under the paternity of God."18

For the Catholic Church, therefore, the media must serve as a means of communicating the faith. But the Catholic Church is not the only one to see the media as instruments for evangelisation. Other religions, such as Islam and other Christian denominations use new media and digital social networks. As the imam of the Grand Mosque of the Riviera Golf in Abidjan says, "Beyond Islam, all religions today use Facebook, because it is a channel through which we can find people, a category of people, especially young people." ${ }^{19}$ These words of this imam are corroborated by Evangelical and Pentecostal pastors and preachers. The latter make abundant use of the new media for communicating the faith and expanding their ministries. They have websites and are present on digital social networks. These means are integral to the communication of faith and the expansion of these religious leaders. They thus make Marshall McLuhan's expression "the true message is the medium itself" a reality. Because the medium determines the conditions for the message, the media are not only means to communicate the faith through the ministries, but constitutive objects of the message of faith to communicate.

Rosalind Hackett reveals this interaction and integration between new media and ministries and communication of faith amongst Pentecostal preachers. ${ }^{20}$ In her

16 Pontifical Council on Social Communication. 1992. "Pastoral Instruction 'Aetatis Novae' on Social Communications on the Twentieth Anniversary of "Communio et Progressio", 22 February, para 11.

17 Second Vatican Council. 1971. "Pastoral Instruction 'Communio et Progressio' on the Means of Social Communication", 23 May, para 12.

18 Second Vatican Council, "Communio et Progressio", para 13.

19 Interview with the imam of the Grand Mosque of the Golf Riviera, Abidjan, Côte d'Ivoire, March 2008.

20 Asamoah-Gyadu JK. 2015. "'We Are on the Internet': Contemporary Pentecostalism in Africa and the New Culture of Online Religion", in Rosalind IJ, Hackett RIJ and Soares BF (eds). 2015. New Media and Religious Transformations in Africa. Bloomington: Indiana University Press, 166 (citing Hackett RIJ. 2009. “Examining the Nexus of Religion, Media, and Conflict in Africa", African Communication Review 2(1):117-130). 
analysis, the personal charisma of the preachers, their popular sermons and the dissemination of these theories on the radio and on the website are all inseparable from the rest of the world. ${ }^{21}$ Hackett concludes that the new media platforms allow the Pentecostal world to grow into the reality of their stories, testimonials and biblical passages that both the expression and the essence of their powers. These and other media are part of the world of information technology and the subject of information technology and communication.

But Hackett's studies also show a rather positive use of new media for communication of faith. In my study, this was not always the case. My terrain and the material that I analyse includes a number of users who I classify as "profane". I consider them to be "profane" or "popular religion" enthusiasts, because their communications through short messages and emails are not part of a well-developed and elaborate pastoral process. It is a question, as well, of the use of mobile phones and digital social networks by these amateurs to broadcast religious messages. These digital social networks serve as a space for the expression of a popular religiosity, often in a spontaneous way imposed by the digital culture and context. In some cases, these networks gave rise to what I call a "deviant popular religiosity".

\section{Digital culture, digital social networks and the expression of deviant popular religiosity}

For purposes of this chapter, social media are taken to be a space of freedom of expression, but also expression of popular religiosity, in Côte d'Ivoire and elsewhere in Africa. The expression "popular religiosity" nevertheless deserves clarification. What is popular religion? To answer this question, we take the definition given by the Belgian theologian Thils Gustave. For Gustave, popular religion means "lived religion - at the level of representations, affects and customs - in a mode of a difference compared to the official religion". ${ }^{22}$ Gustave goes on to say that it is possible to "redefine popular religion as religiosity lived in social groups in their own way (abstraction from the intervention of an ecclesiastical power or dogmatic legitimation)". ${ }^{23}$ What matters here is the word "popular", which Gustave describes as less "cultivated", "critical", "official", "guaranteed", "pure", "mature", "elite", "bourgeois". It thus approaches the point of being "uncultivated", "credulous", "without label", "deviant", "syncretist", "infantile", "mass", "proletarian". In this study, the expression "popular religiosity" refers to "unschooled" or "mass" religiosity. This use of religious messages can be characterised as deviant, immature, lacking maturity and for mass consumption. Umberto Eco, called such amateurs fools when he said: "Social media have given the right of speech to legions of imbeciles.

21 Asamoah-Gyadu, "We Are on the Internet' (citing Hackett, "Examining the Nexus of Religion, Media, and Conflict in Africa").

22 Gustave T. 1977. "La 'religion populaire': approches, definition" [Popular religion: approaches, definition], Revue théologique de Louvain 8(2):202. 
Before, they only spoke at the bar after a glass of wine, without harming the community. They were immediately silenced, while now they have the same right to speak as a Nobel Prize winner. It is the invasion of the imbeciles." 24

\section{RELIGIOUS MESSAGES AND THEIR AUTHORS}

One can classify the authors of the messages sent out over social media according to at least two categories. We have those whom we may call the men of God, that is, shepherds, prophets, servants and such. We also have ordinary citizens - young adults, workers, students, out of school. They all share a regular or assiduous presence on social networks.

\section{Messages of alert and fear}

\begin{tabular}{|c|c|}
\hline AUTHOR OF MESSAGE & CONTENT OF MESSAGE \\
\hline Servant Chantal ${ }^{25}$ & $\begin{array}{l}\text { "The fire of hell and the lightning of the archangels will } \\
\text { meet - Your country will then tremble, everything will be } \\
\text { destroyed for after, be restored to life. Whoever will be } \\
\text { outside will have to crouch and pray. Everything will be in } \\
\text { the faith that each one bears to my Immaculate Heart, as } \\
\text { Mary, Mother of Christian Charity." }\end{array}$ \\
\hline Prophet Séverin Oulaï26 & $\begin{array}{l}\text { "God spoke to me in an audible way. And revealed to me } \\
\text { that he will hit. You are free to believe what I say. This is } \\
\text { not my problem. Only I would like you to know that I am } \\
\text { before you to bear the word of God. Death is coming ... } \\
\text { The destroyer is coming ... And saying it is not politics. } \\
\text { As ambassador of God, I bring the word of the Lord. } \\
\text { Brothers, death is coming. A big wind will blow. A wind } \\
\text { that no one can resist except the children of God. What } \\
\text { I am talking about has never happened in Côte d'lvoire." }\end{array}$ \\
\hline $\begin{array}{l}\text { Anonymous message } \\
\text { posted at AbidjanTV.net }{ }^{27}\end{array}$ & $\begin{array}{l}\text { "I can not guarantee the truth about this message, but it } \\
\text { is better to prevent than to cure. It is said that the coming } \\
\text { Friday is a black Friday; they will kill a lot of people. The } \\
\text { police, gendarmes, dressed bodies say to stay at home, } \\
\text { to close your doors because it will be dangerous. GOD } \\
\text { protect us!" }\end{array}$ \\
\hline
\end{tabular}

24 Leportois D. 2016. "Les nouvelles technologies selon Umberto Eco, ce faux troll” [New technologies according to Umberto Eco, the false troll], Slate, 20 February.

25 Online at: http://mariemeredelacharitechretienne.org/accueil.html/; See also "Libération de la Côte d'Ivoire: La dernière prophétie de la Vierge Marie qui divise l'Eglise catholique" [Liberation of Côte d'Ivoire: The last prophecy of the Virgin Mary which divides the Catholic Church], Ivoire Business, 13 March 2015.

26 “Le Prophète S. Oulaï: Dieu va frapper en Côte d'Ivoire en 2015. Ce qui va arriver ne s'y est jamais produit avant" [The Prophet S. Oulai: God will strike in Côte d'Ivoire in 2015. What will happen has never happened before], Le Forum: Foi Totale en Jesus Christ, 19 March 2015.

27 "Côte d'Ivoir - Psychose des Sms sur les terroristes/ Hamed Bakayoko met en garde ce qu'il dit", AbidjanTV, c.2016. Online at: http://abidjantv.net/technologie/cote-divoirepsychose-des-sms-sur-les-terroristes-hamed-bakayoko-met-en-garde-ce-quil-dit/ 


\section{Messages of prayers and exhortation}

\begin{tabular}{|c|c|}
\hline AUTHOR OF MESSAGE & CONTENT OF MESSAGE \\
\hline $\begin{array}{l}\text { Message from a } \\
\text { source from our } \\
\text { WhatsApp } \\
\text { mailing list. }^{28}\end{array}$ & $\begin{array}{l}\text { "Lord, have mercy on us. See our sufferings! See our wounded } \\
\text { hearts! See our families devastated, destroyed! See our } \\
\text { troubled children! See our distraught young people! See our } \\
\text { efforts to bring peace! And make us peacemakers! Forgive } \\
\text { those who activate tension and conflict by procuring weapons. } \\
\text { Touch their hearts so that they prefer life to death. Forgive } \\
\text { those who profit from this crisis to plunder our country and } \\
\text { its inhabitants. Forgive those who seek power by all means in } \\
\text { defiance of the dignity of the human person and the interest of } \\
\text { the Nation." }\end{array}$ \\
\hline $\begin{array}{l}\text { Message received on } \\
\text { our mobile phone } \\
\text { from someone on our } \\
\text { contact list. }{ }^{29}\end{array}$ & $\begin{array}{l}\text { "Food fortifies the body, but fasting strengthens the soul. Do } \\
\text { not let yourself be outdone by carnal pleasure, because it is } \\
\text { ephemeral. Obey the law of the Prophet Muhammed. Send } \\
\text { this SMS to all Muslims in your contacts and for each person } \\
\text { saved you will have your reward." }\end{array}$ \\
\hline $\begin{array}{l}\text { Message received on } \\
\text { our mobile phone } \\
\text { from someone on our } \\
\text { contact list. }{ }^{30}\end{array}$ & $\begin{array}{l}\text { "I am Jesus. I watch over you day and night but you do not } \\
\text { have time for me. If you spend } 30 \text { minutes of your time praying } \\
\text { to me, you will receive the blessing in abundance." }\end{array}$ \\
\hline $\begin{array}{l}\text { Message received on } \\
\text { our mobile phone } \\
\text { from someone on our } \\
\text { contact list. }{ }^{31}\end{array}$ & $\begin{array}{l}\text { "Good evening. I know we do not know each other, but I } \\
\text { have a message from Allah for you. Tonight, the Angel Djibril } \\
\text { (Gabriel) will be with you. If you believe, then share this with } \\
\text { ten of your contacts, their lives will be changed. I did my part." }\end{array}$ \\
\hline $\begin{array}{l}\text { Message received on } \\
\text { our mobile phone } \\
\text { from someone on our } \\
\text { contact list. }{ }^{32}\end{array}$ & $\begin{array}{l}\text { "Why do you care about your life? The Lord Jesus has a plan } \\
\text { for you/ Do not we say that at } 90 \text { years old Sara conceived? } \\
\text { Baptised, sick for } 38 \text { years, and now cured. Believe and you will } \\
\text { see the glory of God." }\end{array}$ \\
\hline $\begin{array}{l}\text { Message received on } \\
\text { our mobile phone } \\
\text { from someone on our } \\
\text { contact list. }\end{array}$ & $\begin{array}{l}\text { "This is not a joke. Angels know that you are fighting for } \\
\text { something. They say that now it's over, you'll receive a blessing } \\
\text { if you believe in the angels. Send this message, do not ignore it, } \\
\text { because you will be put to the test. Your problems will be fixed, } \\
\text { drop everything and transmit the SMS. Tomorrow will be the } \\
\text { most beautiful day. Send it to } 20 \text { people (including me) and } \\
\text { someone you love will surprise you." }\end{array}$ \\
\hline
\end{tabular}

28 Message posted on 16 May 2017 during the mutiny in Ivory Coast. Soldiers were protesting to claim bonuses. This is an excerpt from the Prayer for Peace in Côte d'Ivoire. Online at: http://www.ssccjm.org/spiritualite/pr_diverses/paix_cote_ivoire.html/. This prayer is elaborated by the Conference of Bishops of Côte d'Ivoire. In Côte d'Ivoire, there is also the National Day of Peace. This national day of peace was instituted in 1996 by Decree No. 96-205 of 7 March 1996. The date of 15 November has since been added to the calendar of public holidays in the country.

29 Received Saturday, 20 June 2017.

30 Received Saturday, 8 July 2017.

31 Received Thursday, 18 June 2017.

32 Received Sunday, 16 April 2017.

33 Received Monday, 10 July 2017. 


\section{WHAT RELIGIOUS LEADERS SAY ABOUT DIGITAL RELIGIOUS MESSAGES}

In general, the religious messages broadcast on social networks arouse suspicion amongst religious leaders, whether Catholic or of other Christian groups. In data collected through interviews, this is evident in the testimonies of Muslim imams and Catholic priests, as well as excerpts from a statement by the bishops of Côte d'Ivoire following the broadcast of a message about the Virgin Mary. For example, Imam Sylla Sekou, imam of the Mosque Nour of Riviera 2 and the spokesperson of the Higher Council of Imams of Côte d'Ivoire, noted that amongst the shared messages, some relate to peace and fraternity. These messages are to be encouraged, the Imam maintained, because they go in the direction of the teaching of Islam. As he put it, "In cases of confrontation and resentment, the messages that go in the direction of peace are to be encouraged, because they permit us to anticipate negative reactions before intervention by religious guides to extol peace. Islam itself is a word that comes from the word 'salaam' which means peace. This is to say that the peace that we transmit, the peace is peace with the community, peace with the Lord." ${ }^{34}$

In a similar vein, the imam of the Grand Mosque Mosque Nour of Riviera 2 said, "I do not think hate messages can come from Muslims. Because during the post-election crisis, we Muslim religious leaders made an effort to pacify Muslims through Radio Albayane, interventions on international radio stations like Radio France Internationale (RFI) and British Broascating Company (BBC)." ${ }^{35}$ According to the imam of the Plateau Mosque, "In times of crisis, as we are many believers in Côte d'Ivoire, it is necessary to encourage religious messages that convey peace and cohesion. But on the contrary, no religious leader, no matter what, can encourage messages that use religion to pit people against each other or to convey hatred between different communities." ${ }^{\prime 36}$ But an evangelical Christian pastor invoked another aspect of the religious messages. In his view, "The Lord never took sides. Common sense dictates that as men of God, we avoid taking sides. Faced with messages that can create psychosis, the pastor can send messages of comfort to the faithful to tell them that God is in control, so that they remain serene." ${ }^{37}$

Contrary to the rather positive positions of the imams and the evangelical pastor, the hierarchy of the Catholic Church in Côte d'Ivoire distanced itself following the spread of the aforementioned message of the Virgin Mary social networks. This can be seen in excerpts from their statement on the matter, in which they admonished: "Some people, claiming to represent the Catholic Church, have given themselves the mission to broadcast by emails or SMS messages, which according to the

34 Interview with Imam Sylla Sekou, imam of the Mosque Nour of Riviera 2, COSIM spokesperson, by C Gnonzion, Abidjan, Côte d'Ivoire, March 2018.

35 Interview with Imam Sekou Sylla.

36 Interview with Coulibaly Soungalo El Hadj, imam adjoint of Plateau Mosque Salam, by C Gnonzion, Abidjan, Côte d'Ivoire, March 2018.

37 Interview with Ghislain Sagba, pastor of Evangelical Bethesda Church, by C Gnonzion, Abidjan, Côte d'Ivoire, March 2018. 
messages' authors, came from the Virgin Mary. The argument is that the content of these messages is contrary to the of the Gospel of Christ Jesus and the teaching of the Catholic Church. Therefore, the effect of some of the messages was to disturb the public order and created psychosis and the fear in the heart of our population, which has already suffered. ${ }^{38}$

The reaction of the Ivorian bishops and archbishops to this message is understandable, because this type of message could allow for belief in an appropriation of the Virgin Mary that could pit one group of Ivorians against another. However, a Catholic priest, while denouncing the "invasive" nature of these messages, nevertheless affirmed that "they are the expression of a strong feeling of increasing religiosity in Africa". ${ }^{39}$ For him, "these messages are part of the class of new forms of religion that fill the world with different evangelisations." 40 He thinks that "poverty in Africa and the socio-political crises that keep it alive mean that many Africans are feeding on hope and promises of miracles" ${ }^{\prime 4}$ In the view of this priest, the Catholic Church hierarchy should keep it believers on guard against these practices. The Church hierarchy often reminds the people that the official messages of the Church are given in the churches, not via SMS. Messages in the form of "share with ten people and you will be blessed" are strongly criticised by the Catholic Church. Blessings are not a matter of calculations and mathematics.

The Church also categorically opposes any social media message that could be seen to disrupt social cohesion or be used as a conduit to pass along such a message. For the Church, everyone is free to practise the religion he wants. Another priest, the curate of a Catholic parish in Abidjan stresses that "God does not change our salvation, and the healing that God gives is not necessarily linked to the faith, only God wants when he wants and how he wants". ${ }^{42}$ He continues, "It is up to the pastors to work on this, to help them understand that God is not a merchant God. He is a God who gives freely his salvation, to whom he wants, when he wants." 43 The authors of certain messages on social networks or mobile phones "make this God a magical God". ${ }^{44}$ In their view, "A God who does not produce a miracle is not a God. It is God who produces miracles." ${ }^{45}$ He continued: "God is not a god of

Bishops of Côte d'Ivoire. 2015. Statement following the message of Servant Chantal of the Community Mary Mother of Christian Charity. Online at: https://www.cath.ch/newsf/ mise-en-garde-des-eveques-ivoiriens-contre-des-sms-de-la-vierge-marie/

Interview with Father Etty Rodolphe Koffi, member of the communication service for the Diocese of the Catholic Church of Abidjan, by C Gnonzion, Abidjan, Côte d'Ivoire, April 2018.

Interview with Father Etty Rodolphe Koffi.

Interview with Father Etty Rodolphe Koffi.

Interview with Father Serge Lorougnon, curate of the parish of Saint Philippe d'Abobo, by C Gnonzion, Abidjan, Côte d'Ivoire, April 2018.

Interview with Father Serge Lorougnon.

Interview with Father Serge Lorougnon.

Interview with Father Serge Lorougnon. 
retribution. God does not say, 'You have this, you are entitled to that.' He is, rather, a God who shines his sun on both good and bad."46

\section{ETHICAL CHALLENGES TO SOCIAL COHESION}

In Côte d'Ivoire, the dangers of religiously motivated hate messages broadcast on the RSNs are real. These messages emanate from not only ordinary citizens, but also from religious leaders, two of whom were arrested by the public prosecutor for acts of incitement to xenophobia and hatred, as mentioned above. There is certainly no direct and verified link between the spread of these messages and acts of violence and disturbance of public order. But the interest of this study is to show that the spread of messages with religious connotations that arouse fear, creates psychosis or incites hatred can be dangerous. Susan Benesch, who has worked on the link between dangerous speech and mass violence, helps us to understand that:

Hate speech is variously defined in law and in common parlance, but is generally understood to mean speech that denigrates people on the basis of their membership in a group, such as an ethnic or religious group. This category of speech is too broad for successful early warning of mass atrocities, for two related reasons. First, hate speech is common in many societies, unfortunately, including those at minimal risk of genocide. Second, some hate speech does not appreciably increase the risk of mass violence, although it may cause serious emotional and psychological damage. In other words, speech can harm directly or indirectly, or both. ${ }^{47}$

A core ethical issue posed by these posts and messages sent out over various messaging platforms relates to freedom of expression and the right to communicate. Citizens must be free to speak on matters of national interest. They must speak and communicate, because communication is a fundamental human right. But freedom of expression and the right to communicate also require the right of respect for the human person. We are free to communicate to promote dignity, cohesion, peace and social and human well-being. However, it is also necessary to frame the free flow of communication and information on digital social networks and the various messaging platforms through education. This education should focus on laws and regulations related to digital communication. The sensitisation of the users of social media can also be done by deterrent action, as the Ivorian justice system did in March 2018. Then, the Abidjan Criminal Court condemned a young user to twelve months in prison and a fine of five million CFA francs for "incitement to violence" on the social network Facebook. The individual had called for murder and violence against families of gendarmes. The rapid expansion of internet users with evolution from $2 \mathrm{G}$ to $4 \mathrm{G}$ technology has provided users with easy and democratic access to social networks. Everyone profusely exercises their right to speak.

46 Interview with Father Serge Lorougnon.

47 Benesch S. 2012. Dangerous Speech: A Proposal to Prevent Group Violence. 12 January. Online at: https://worldpolicy.org/wp-content/uploads/2016/01/Dangerous-Speech-Guide lines-Benesch-January-2012.pdf 
But the specific socio-political context of Côte d'Ivoire should also be challenged. Because this exercise of the right to speak, through digital social networks takes place in a social and political context already marked by divisions based in political and religious ideology. This raises challenges for peace and social cohesion. The first challenge for social cohesion will be to moderate debates on social networks, to give voice to people who can raise the level of debate. Because some religious messages on social media incite fear, division and hate, it may be necessary to close accounts or sanction users for hostilities that threaten peace and social cohesion. It is also possible to trace the perpetrators and to investigate those who incite hatred and xenophobia. The second challenge is that social media makes us insensitive to the suffering of others. When faced with disasters, accidents and misfortunes, we are obsessed with capturing images to share on our Facebook pages instead helping those who need our aid and assistance. The third challenge is that under the cover the use of religious words and expressions, users of social media reveal their individualism and selfishness.

Faced with these challenges, the authorities in charge of telecommunication regulation in Côte d'Ivoire should be able to produce a guiding framework to punish authors on social networks for writings that incite hatred, division and xenophobia. These authorities can draw from the example of regulations governing the written press. They have filters that allow them to sanction journalists for unethical writing that incites hatred and xenophobia. To this end, in the light of this volumes theme of law, religion and human flourishing, this chapter has attempted to emphasise the link between religiosity, self-fulfilment, social cohesion and peace. We have shown that new media are used to communicate the faith and religiosity of some users. But in a context already marked by divisions and political polarisation, messages can deviate from their targets and be interpreted as carrying genes for hatred.

\section{CONCLUSION}

This analysis of the use of religious messages digital social networks in Côte $\mathrm{d}^{\prime}$ Ivoire has been an exploratory study in the face of a phenomenon that is growing with the ease of access to the internet. It is an attempt to understand this problem by presenting examples of these religious messages in order to observe not only the ethical issues they raise, but also the challenges they pose for social cohesion in Côte d'Ivoire. Messages broadcast on digital social networks have shown that amateurs, as well as pastors, servants of God or people claiming to be such, can broadcast messages that may alarm or incite hatred. But in the majority of cases, these messages are not part of a well-constructed and elaborated pastoral process. Digital social networks thus serve as a space for the expression of popular religiosity, but often in a spontaneous way imposed by digital culture and context.

These different presences on the web for contradictory purposes remind us of the need for Christians and people of good will to be trained and sensitised in their use of social media. As Catholic theologian Anthony Spadaro points out, "The web 
is not an instrument, but an environment in which we live ${ }^{48} \ldots$ If Christians think about the internet, it's not just to learn how to use it well, but because they are called to help humanity understand the deeper meaning of the net itself in the project. God: not as an instrument to use but as a medium to 'inhabit'."49 Spadaro notes that "grace lives on the same territory as the devil and gradually invades it". ${ }^{50}$ Spadaro insists that if we see so much harm on the net, we cannot rest on the laurels of a negative judgment, if we want to see God at work in the world.

The enthusiasm and dynamism of different actors on social networks in Côte d'Ivoire demonstrate their willingness to communicate and share what they live and what they believe. It is a sign of freedom of expression, which, of course, can carry with it the non-respect of certain values of life in a plural and multicultural society. This is why, for the development of the authors of these messages on social networks in Côte d'Ivoire, some of whom are fooled by ignorance or lack of training, there should be a genuine culture of responsible dialogue and concern about the diversity of social media expressions - we can say everything, provided that we have courtesy and respect for others who may have a different belief and vision.

48 Spadaro A. 2014. Cyberthéologie: penser le christianisme à l'heure d'internet [Cybertheology: thinking about Christianity at the time of the internet]. Brussels: Lessius, 1.

49 Spadaro, Cyberthéologie, 9-10.

50 Spadaro, Cyberthéologie, 11. 